\title{
沈砂池のストックマネージメントに関する経済分析
}

一赤土流出対策と沿岸生態系の保全一

\author{
川島 滋和 1$) *$
}

\section{Sustainable Management of Sediment Retention Ponds to Mitigate Degradation of Coastal Fisheries and Ecosystem: The Case of Ishigaki Island, Okinawa, Japan}

\author{
Shigekazu Kawashima ${ }^{1) *}$
}

Soil erosion, often referred to as "red soil erosion," has been considered as a major environmental issue in Ishigaki Island. It affects not only sugarcane farming, but also the degradation of fisheries, coastal ecosystems, and coral reefs, eventually leading to economic loss in tourism. This study sheds light on the management strategy of sediment retention ponds as many of them remain unmanaged and filled with sediments, gradually degrading coastal fisheries and ecosystems. An economic model was developed to illustrate how sediment retention ponds are sustainably managed under alternative scenarios. This study suggests that frequent dredging in sediment retention ponds is required to reduce the management and environmental costs. It also focuses on the effective use of dredged sediment and community-led management.

キーワード : 沈砂池, 赤土対策, サンゴ保全, 浚渫, 資源管理

\section{1. はじめに}

沖縄県の赤土等の土砂流出は, 1960 年代半ば以降 に社会問題として認識されるよらになった. 1971 年 の沖縄振興開発特別措置法を皮切りに, 赤土流出防 止条例の制定や沖縄県赤土等流出防止対策基本計画 が策定された。赤土の流出は, 農業経営や沿岸漁業 への影響にとどまらず, 沿岸生態系やサンゴ保全, さらには観光業や地域経済への影響も危惧されてい る. かつて赤土の流出源は開発事業によるものであっ

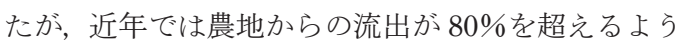
になっている.

赤土の流出削減対策は, 農学的手法と工学的手法 に大別される. 農学的手法とは, マルチング, 横畋 栽培, 緑肥, グリーンベルト（ゲットウ, 八イビス カス, ベチバー等), サトウキビの株だし栽培等であ
る. 作付品目や農法を変更することで, 固場レベル での土砂流出を抑制する方法である．坂井他（2015） は，圃場レベルでの対策が進まない理由として，農 業の外部不経済の問題を挙げている. 農学的手法を 用いた追加的対策費用を政策介入によって支援しな い限り, 赤土流出問題の解決は難しいとしている（坂 井他, 2015).

他方, 工学的手法とは, 勾配修正, 排水路の整備, 沈砂池の設置である. 沈砂池とは, 農地から流れ出 た土砂が海へ流出する前に貯水池に一旦貯め, そこ で土砂を沈砂させることで，海への土砂流出を軽減 する貯水池のことである．比嘉他（1994）は，沈砂 池の設置によって土砂流出量が 4 割から 6 割削減で きるとし，USLE (Universal Soil Loss Equation) に 基づく土砂流出量の予測に拈いて保全係数として

\footnotetext{
1) 宮城大学食産業学群; School of Food Industrial Science, Miyagi University

*E-mail: kawashim@myu.ac.jp

(地域農林経済学会
} 
0.4〜0.6を乗じることを提唱している. 沈砂池の設 置は, 重要な赤土対策と位置づけられ, 沖縄県石垣 島だけで約 300 の沈砂池があると言われている. し かしながら, 多くの沈砂池では浚渫が行われておら ず，その機能を十分に果たしているとは言い難い状 況である. 赤土の流出対策としての沈砂池の効果に ついては，工学的な視点から検証されてはいるが 1 , 維持管理に関する研究は寡聞にしてしらない. 本研 究は, 沈砂池の持続的な資源管理, つまりストック マネージメントの経済分析を通じて, 沿岸漁業・生 態系保全を促す資源管理モデルを考察することを目 的とする。

\section{2. 石垣島の農業，土砂流出，環境被害}

石垣島の耕地面積は約 5300 ha であり, 782 の農業 経営体（販売農家）がある（石垣市, 2020). 農業 経営体の約 6 割はサトウキビやたばこ等の工芸農作 物を作付けし, 農業産出額では石垣牛で有名な肉用 牛が全体の約 7 割を占めている. 沖縄県赤土等流出 防止対策基本計画の中で, 石垣島海域も土砂流出量 が多い重点監視海域に指定されている. 表 1 は, そ の重点監視海域の農地面積と土砂流出量である. 沖 縄県赤土等流出防止対策基本計画では, 2021 年まで にこの流出量を約半分にすることを目標としている (沖縄県, 2014).

流出した赤土は沿岸漁業へ被害をもたらす，沿岸 漁業への被害としては, モズクを中心に一漁協あた り 2000 万円前後の被害が報告されている（只,

表 1. 流域別の農地面積と土砂流出量

\begin{tabular}{lccc}
\hline \hline 重点監視区域 & $\begin{array}{c}\text { 農地面積 } \\
(\mathrm{ha})\end{array}$ & $\begin{array}{c}\text { 流出量 } \\
(\mathrm{t})\end{array}$ & $\begin{array}{c}\text { 面積めたり } \\
\text { 流出量 }(\mathrm{t} / \mathrm{ha})\end{array}$ \\
\hline 平久保地先海域 & 208.72 & 2540.69 & 12.2 \\
伊原間湾 & 167.27 & 1482.49 & 8.9 \\
野底崎南海域 & 39.85 & 317.53 & 8.0 \\
浦底湾 & 31.94 & 394.49 & 12.4 \\
川平湾 & 113.39 & 1513.72 & 13.3 \\
枝崎湾 & 75.39 & 1110.27 & 14.7 \\
名蔵湾 & 605.54 & 6000.19 & 9.9 \\
石垣島東南海域 & 663.2 & 9282.3 & 14.0 \\
宮良湾 & 1075.42 & 17032.35 & 15.8 \\
\hline 計 & 2980.7 & 39674.0 & 13.3 \\
\hline
\end{tabular}

資料: 沖縄県 (2014)『沖縄県赤土等流出防止対策基本計画』
2000)。しかしながら，こうした被害は金銭的に評 価できる汪んの一部であって，沿岸生態系やサンゴ 礁への経済的損失についての評価は極めて難しい. 沖縄県赤土等流出防止対策基本計画では，サンゴ礁 の経済的価值として，観光・レクリエーション $(2324$ 億円/年)，漁業（106 億円/年），海岸防護機能（559 億円/年) 等の数值を紹介している ${ }^{2}$ (沖縄県, 2014).

\section{3. 沈砂池の資源管理モデルの経済分析}

沈砂池への流入土砂量を $M$, 沈砂池の初期容積 を $S_{0}$, 沈砂池での土砂の捕捉率（trap efficiency）を te とするとき, 有効容積 $S_{t}$ のときの沈砂池の堆積土 砂量を次のと扣り定義する。

$$
M \cdot t e \cdot \frac{S_{t}}{S_{0}}
$$

有効容積が初期容積と等しいとき $\left(S_{t}=S_{0}\right)$, 堆積 土砂量は， $M$ とte の積として表される．海へ流出す る土砂量 $\left(E_{t}\right)$ は, 沈砂池に入ってきた土砂量 $(M)$ と堆積土砂量の差になるので次のようになる。

$$
E_{t}=M-M \cdot t e \cdot \frac{S_{t}}{S_{0}}=M \cdot\left(1-t e \cdot \frac{S_{t}}{S_{0}}\right)
$$

例えば，有効容積がゼロ $\left(S_{t}=0\right)$ のときは，沈砂 池の堆砂機能がないため, 流出土砂量 $\left(E_{t}\right)$ は流入 土砂量 $(M)$ と等しくなる. $t$ 年における浚渫土砂量 を $X_{t}$ とすると, 沈砂池の有効容積 $S_{t}$ の変化は以下 のよらに定義できる。

$$
\begin{aligned}
S_{t+1} & =S_{t}-M \cdot t e \cdot \frac{S_{t}}{S_{0}}+X_{t} \\
& =\left(1-M \cdot t e \cdot \frac{1}{S_{0}}\right) S_{t}+X_{t}
\end{aligned}
$$

$S_{t}$ の前の係数を $\alpha$ に置きかえると次のようになる.

$$
S_{t+1}=\alpha \cdot S_{t}+X_{t} \quad(\alpha<1)
$$

浚渫が実施されないかぎり沈砂池の有効容積は一 定割合 $(\alpha<1)$ で小さくなり，その結果，沿岸への 流出土砂量 $\left(E_{t}\right)$ の増加を招くことになる、浚渫を 実施すれば $\left(X_{t}>0\right)$, 沈砂池の有効容積は増え, 流 出する土砂量を抑制することができる.

次に, 海への土砂流出による環境費用 $\left(E C_{t}\right)$ は, 土砂流出量 $\left(E_{t}\right)$ の増加関数と仮定する $(\alpha 2>1)$.

$$
E C_{t}=\alpha 1^{*}\left(E_{t}\right)^{\alpha 2}
$$


環境費用と浚渫費用はトレードオフの関係にある. 沈砂池のストックマネージメントを実施すれば，浚 渫費用は発生するが, 土砂流出量は軽減し, 将来的 な環境費用を抑制できる。何もしないと当座の浚渫 費用は節約できるが，沈砂池が土砂で埋まるにつれ て海への土砂流出は増大し, 環境被害を生じること になる。

浚渫費用 $\left(C_{t}\right)$ は, 浚渫土砂量の一次関数とする.

$$
C_{t}=c 2 * X_{t}
$$

以上をまとめると, 沈砂池の資源管理問題は, 浚 渫土砂量 $\left(X_{t}\right)$ を操作変数, 有効容積 $\left(S_{t}\right)$ を状態 変数として, 環境費用 $\left(E C_{t}\right)$ と浚渫費用 $\left(C_{t}\right)$ の最 小化を目的とする動的問題として扱らことができる.

$$
\operatorname{Min} \int_{0}^{\infty} \mathrm{e}^{-r * t}\left(E C_{t}\left(S_{t}\right)+C_{t}\left(X_{t}\right)\right) d t
$$$$
\text { s.t. } S_{t+1}=\alpha \cdot S_{t}+X_{t}
$$

沈砂池の有効容積を「再生可能資源」としてとら 兄, 沿岸漁業や生態系への環境費用及び浚渫費用の 最小化問題から沈砂池の資源管理のあり方を考察 する ${ }^{3}$.

上記の動的問題は, 以下のハミルトニアン $(H)$ の最大化問題として解ける.

$$
H=e^{-r^{*} t}\left(E C_{t}+c 2 \cdot X_{t}\right)+\lambda\left(\alpha \cdot S_{t}+X_{t}\right)
$$

八ミルトニアンは Most Rapid Approach Path の条 件を満たしており, 最適な有効貯水容積 $\left(S_{t}^{*}\right)$ が存 在し, その有効容積を維持することが最適解となる (Kamien and Schwartz, 1991). 最適有効容積を決定 する関係式は（1）式に表される.

$$
-E C^{\prime}\left(S_{t}^{*}\right)=c 2 *(\mathrm{r}+(1-\alpha))
$$

（1）式左辺は, 最適有効容積を増やしたときに避 けられる限界環境費用である。浚渫を実施して有効 容積を確保しておけば, 海への土砂流出量を減らし， 結果として沿岸漁業や生態系への被害を軽減できる. そのため（1）式左辺は, 沈砂池の資源管理によって 削減できる環境費用の限界価值と解釈できる. 右辺 の $c 2$ は, 浚渫費用の単価である. 短期的（静的）最 適化問題であれば，限界環境費用と浚渫費用が等し いところで最適有効容積は決定される。しかしなが
表 2. 最適容積の比較動学

\begin{tabular}{cccccccc}
\hline \hline & $\alpha 1$ & $\alpha 2$ & $M$ & te & $S_{0}$ & $r$ & $c 2$ \\
\hline$S^{*}$ & + & + & + & + & - & - & - \\
\hline
\end{tabular}

ら，将来にわたり持続的に維持管理することを念頭 に打けば，割引率 $(r)$ と堆砂率 $(1-\alpha)$ を用いて, 割引現在価値として評価されなければならない，長 期的かつ持続的な資源管理の意思決定では，最適有 効容積 $\left(S_{t}^{*}\right)$ は, 短期的最適化問題と比べて極めて 大きくなる。現状の沈砂池管理において浚渫が十分 に行われていない背景には，環境費用が考慮されて いないことに加え，長期的かつ持続的な視点を持っ た意思決定が行われていない可能性が考兄られる. 上記の均衡解からそれぞれの変数が変化したときの 比較動学の結果を表 2 に示した.

土砂流出による環境被害が大きい $(\alpha 1, \alpha 2$ の值が 大きい）ところ医ど，頻繁に浚渫を実施して最適容 積 $\left(S_{t}^{*}\right)$ を大きく維持する必要がある。同様に，土 砂流入量 $(M)$ が多い， あるいは捕捉率 $(t e)$ が高 い沈砂池ほど堆砂機能を維持するために最適容積を 大きくして和く必要がある。他方, 流入土砂量に対 して大きな沈砂池 $\left(S_{0}\right)$ であれば問題を先送りでき るため最適容積は小さくなる，割引率 $(r)$ が高い注 ぞ，沈砂池が土砂で埋まり，その機能を果たさなく なったときに生じる環境費用は割引されるので，問 題を先送りするインセンティブとなる. 最後に, 浚 渫費用（c2）が高くなると当然のことながら浚渫の 頻度, 量は少なくなり, 結果的に最適容積も小さく なる．上記の沈砂池の資源管理モデルは沈砂池のマ ネージメントに関していくつかの示唆を与える．第 一に，環境費用と浚渫費用の合計を最小化している が，環境費用が明示的に認識されないかぎり，「何も しない」ことが最適解となる. 第二に, 沈砂池が土 砂で埋まるまでは問題を先送りできるため, 特に, 割引率や浚渫費用が高い場合には，そうした結論に 導かれやすい.

\section{4. 流域を対象とした沈砂池資源管理モデル （1）複数の沈砂池の資源管理モデル}

前節の資源管理モデルは，個々の沈砂池を対象と していたが，実際には流域にいくつもの沈砂池が存 
在する.この節では, 多数の沈砂池が存在する流域 を想定し, 資源管理モデルの解を数值解析よって得 て, その結果から流域を対象とした最適な資源管理 モデルについて考察する.

一つ目の修正は, 流域に設置された沈砂池の数を $n$ とし, 流域全体からの流出土砂量を $n^{*} E_{t}$ とする. そのときの流域全体の環境費用は, 以下のように定 義できる.

$$
E C_{t}=\alpha 1 *\left(n^{*} E_{t}\right)^{\alpha 2}(\alpha 2>1)
$$

流域内での沈砂池数の増加に伴い土砂流出量は正 比例で増えるが，環境費用は正比例以上に増加する と仮定している.

次に，セットアップ費用を資源管理モデルに追加 する、浚渫を行らには, ショベルカー等の重機を用 意する必要があり, 浚渫量にかかわらず発生する費 用が少なからず存在する。 そのために, 浚渫費用を 以下のよらに再定義する.

$$
\begin{cases}C_{t}=n^{*}\left(c 1+c 2 * X_{t}\right) & \left(X_{t}>0\right) \\ C_{t}=0 & \left(X_{t}=0\right)\end{cases}
$$

セットアップ費用（c1）を取り入れることで，八 ミルトニアンが不連続な関数となり，3 節で示した 解析的均衡解を得ることはできない. そこで, ダイ ナミックプログラミングを使った数值解を導出する. 資源管理問題を数値的に解くために, 操作変数 $\left(X_{t}\right)$ と状態変数 $\left(S_{t}\right)$ を初期容積の $0.5 \%$ 刻みにして表現 し，ポリシーイタレーションアルゴリズムを使って 解いた (Miranda and Fackler, 2002).

表 3 は, ダイナミックプログラミングに使ったパ ラメーターである. 捕捉率はUSLEの保全係数とし て使われている 0.6 とした。浚渫費用の単価 $(c 2)$ は小川他（2005）の数值を使い, 七ットアップ費用 （c1）は10万円とした. その他の数值は沈砂池の標 準的な值を用いている. 環境費用のパラメーターは, 定数（ $\alpha 1 ）$ を 1000 円，指数 $(\alpha 2)$ を 1.3 とした. こ の数值を基に, 表 1 の重点海域の土砂流出量から環 境費用を計算すると, 平久保地先海域で約 2700 万 円，伊原間湾で約 1300 万円となる. これらの数值 は，呉（2000）で報告されているモズク等への漁業 被害金額に近くなる，一方，指数 $(\alpha 2)$ を 1.5 とす ると環境費用は飛躍的に拡大寸る（図 1). $\alpha 2=1.5$
表 3. 数值解析のパラメーター

\begin{tabular}{lccr}
\hline \hline \multicolumn{1}{c}{ 変数 } & 表記 & 単位 & \multicolumn{2}{c}{ 数值 } \\
\hline 割引率 & $r$ & $/ 1$ 年 & 0.03 \\
流入土砂量 & $M$ & $\mathrm{~m}^{3}$ & 75 \\
捕捉率 & $t e$ & & 0.6 \\
初期容積 & $S_{0}$ & $\mathrm{~m}^{3}$ & 500 \\
費用関数 & & & \\
$\quad$ セットアップ費用 & $c 1$ & 円 & 100,000 \\
$\quad$ 浚渫費用の単価 & $c 2$ & 円 $/ \mathrm{m}^{3}$ & 3500 \\
環境費用 & & & \\
$\quad$ 定数 & $\alpha 1$ & 円 & 1000 \\
$\quad$ 指数 & $\alpha 2$ & & 1.3 \\
流域内の沈砂池の数 & $n$ & & $1, \quad 5,10$ \\
\hline
\end{tabular}

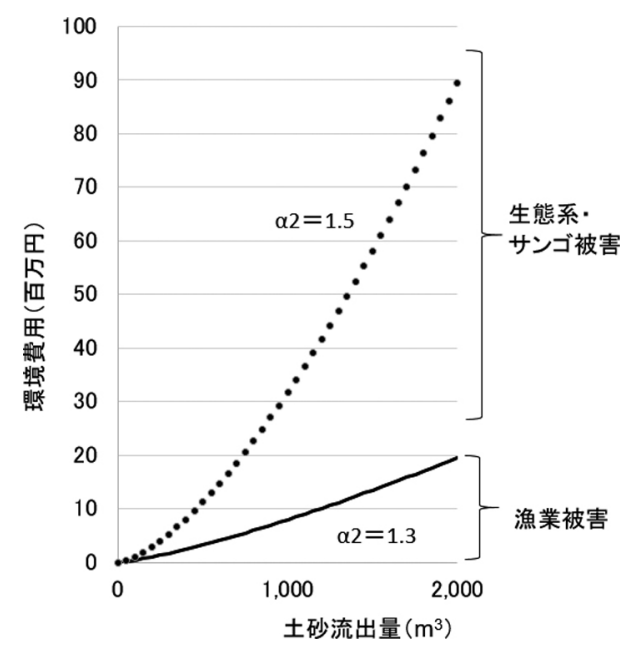

図 1. 土砂流出量と環境費用

のときは, サンゴ礁や沿岸生態系への被害に伴う環 境費用を含む想定である 4 .

\section{(2) 分析結果}

表 3 のパラメーターを使った最適な有効容積の推 移は図 2 となった。流域に沈砂池が一つしかない場 合 $(n=1)$ は，「何もしない」ことが最適解となっ た. 何もしないと 7 年後に $50 \%$ の有効容積を失い, 15 年後には初期容積の 4 分の一しか残っていない. 流域内の沈砂池が少ないときには，たとえ赤土が海 に流出してもその被害は少ないため, 浚渫費用をか けるよりかは「何もしない」ことが最適解となる.

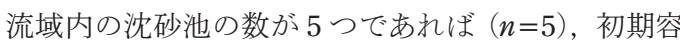
積の $43 \%$ を失ったときに，沈砂池の数が 10 であれ 


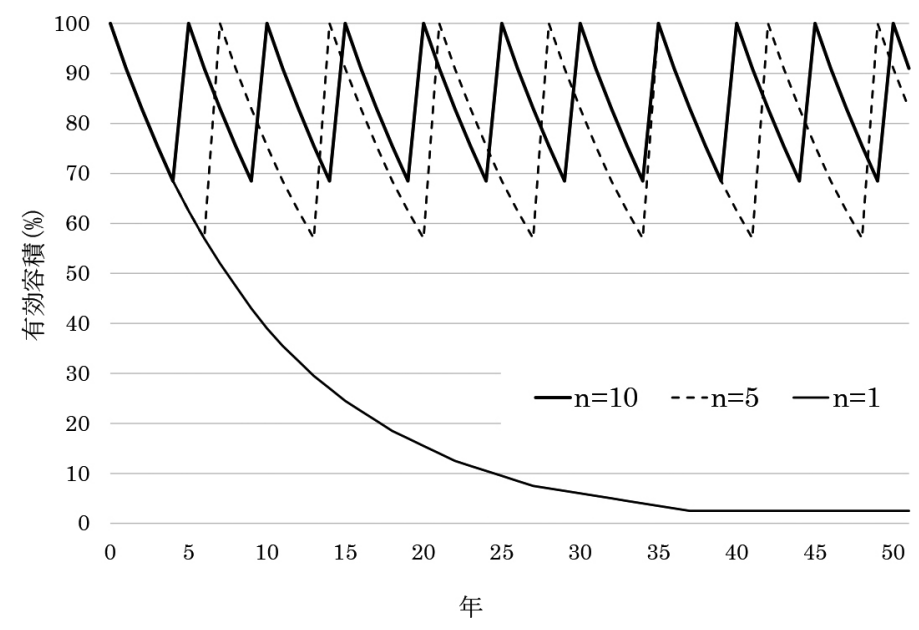

図 2. 最適な沈砂池管理 : 有効容積の推移

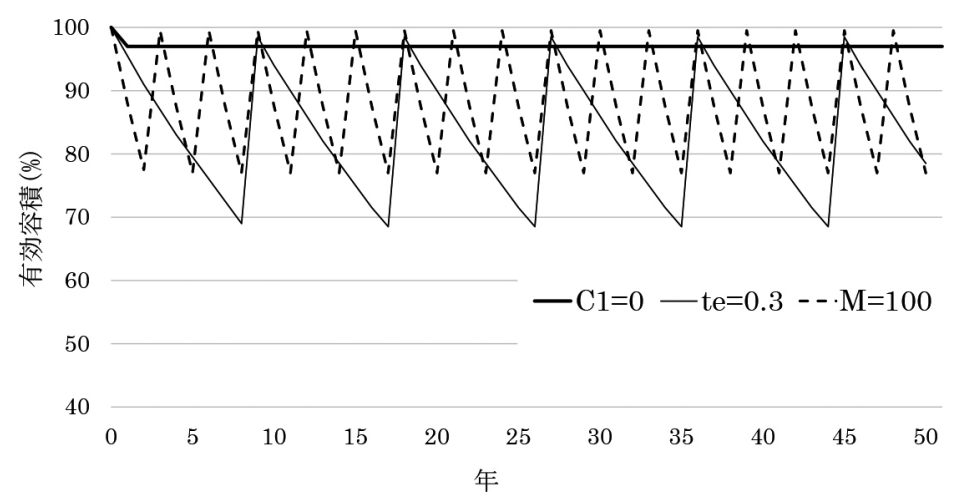

図 3. 最適有効容積の推移: シミュレーション

ば $(n=10), 32 \%$ の有効容積を失ったときに浚渫を 実施することが最適となる。初期容積の 6 割から 7 割を維持するように浚渫を実施している。つまり， 土砂流出量が多く, 沈砂池が多く設置されている流 域ほど頻繁に浚渫を実施して, 環境被害を軽減させ る必要があることを示唆している. 上記のようなス トックマネージメントが実施された場合, 海へ流出 する赤土の量を約 5 割から 6 割削減することができ る.

図 3 は, $n=10$ の下で, 他のパラメーターを変化 させたときの最適な有効容積の推移である。まず, セットアップ費用 $(c 1)$ をゼロにすると, 初年度を 除き毎年浚渫を実施して，97\%の有効容積を維持す ることが最適解となる。 セットアップ費用がないた
め, 一度に多くの土砂を浚渫するメリットはなくな る. Most Rapid Approach Path に見られるように，一 旦最適有効容積に到達したら，それを維持すること が最適行動となる (Kamien and Schwartz, 1991)。こ 孔は 3 節 (1) 式で示した解析的均衡解の存在と整合 的な結果となっている.

次に, 沈砂池での捕捉率 $(t e)$ を 0.6 から 0.3 に変 更させた場合，維持すべき最適有効容積に大きな変 化はなかった．図 2 では初期容積の $32.5 \%$ 土砂が埋 まったら浚渫を実施すべきとの解であったが，図 3 では $31 \%$ の容積が失われたときに浚渫をすべきとの 結果になった。大きな違いは, 浚渫の間隔である. 捕捉率が低い場合，沈砂池に土砂が溜まりづらくた め, 有効容積を失らスピードが遅い。図 2 の浚渫の 
周期は 5 年であったのに対して，図 3 の浚渫の周期 は 9 年と 4 年も長くなっている. 現状の沈砂池の資 源管理において, 浚渫があまり実施されていない背 景には, 沈砂池の補足率は想定している值よりも低 く, 堆砂機能を十分に果たしていない可能性も考え られる。

最後に, 流入土砂量を $M=75$ から $M=100$ に変更 したときの結果を示した. 図 2 では初期容積の $68 \%$ で浚渫を実施しているが，図 3 では図 2 より約 $10 \%$ も多く有効容積を維持している. 表 2 の比較動学の 結果のと扣り, 流入土砂量が多いところほど, 浚渫 を頻繁に実施して沈砂池の堆砂機能を高く維持する ことが経済的に最適であると示された.

（3）沈砂池のストックマネージメントの経済分析

沈砂池のストックマネージメントを実施したとき としなかったときの割引現在価値を表 4 に示した. ダイナミックプログラミングの結果から最適資源管 理が行われた場合の割引現在価值を算出できる. 表 4 左は, 漁業被害のみを想定したとき $(\alpha 2=1.3)$ の 結果であり, 表 4 右は, サンゴ礁や沿岸生態系への 被害と漁業被害の両方を想定したとき $(\alpha 2=1.5)$ の 結果である. 表 4 の「浚渫によるストックマネージ メント」は, 浚渫費用と環境費用の割引現在価値を 示している. また, 「何もしない」は, 浚渫を実施し
なかった場合の環境費用の割引現在価值である.

「何もしない」に比べて, 浚渫費用之環境費用の合 計が最大で $24.4 \%$ 抑制されている (表 4 左). 特徵 的なのは，沈砂池のストックマネージメントの経済 効果は，流域での土砂流出量が多いところ臣高い ことである。つまり，固場レベルでの農学的手法に よる赤土対策が難しく, 沈砂池への流入土砂量が多 い地域ほど，沈砂池による赤土対策の経済効果が高 いことを示唆している. また，流域に多くの沈砂池 が設置されているところほど，浚渫によるストック マネージメントの経済効果が高いことが明らかに なった。

流域内の沈砂池数が一つのときのダイナミックプ ログラミングの最適解は「何もしない」になった（図 $2, n=1)$. このような場合には, ストックマネージ メントの経済効果はゼロとなる (表 4 左). 石垣島の 流域内には多数の沈砂池が設置されている．石垣島 の農業流域に打ける土砂動態を分析した大澤他 （2004）の研究によれば，流域面積 12.5 haに対して 大小 9 基の沈砂池があると報告されている. そのた め, 農業地域内の土砂流出量が多く, 寸でに多くの 沈砂池が設置されている流域では，浚渫費用をかけ ることによって赤土による環境被害を大幅に抑制て きる可能性を示唆している。

表 4. ストックマネージメントの経済効果

\begin{tabular}{|c|c|c|c|c|c|c|}
\hline & \multicolumn{3}{|c|}{ 漁業被害（ $\alpha 2=1.3 ）$} & \multicolumn{3}{|c|}{ サンゴ・生態系被害+漁業被害（ $\alpha 2=1.5 ）$} \\
\hline & \multicolumn{3}{|c|}{ 流域に打ける沈砂池の数 } & \multicolumn{3}{|c|}{ 流域における沈砂池の数 } \\
\hline \multirow[t]{2}{*}{ 流入土砂量 } & $\mathrm{n}=10$ & $\mathrm{n}=5$ & $\mathrm{n}=1$ & $\mathrm{n}=10$ & $\mathrm{n}=5$ & $\mathrm{n}=1$ \\
\hline & \multicolumn{3}{|c|}{$\begin{array}{c}\text { 浚渫によるストックマネージメント } \\
\text { 環境費用+浚渫費用 (A) }\end{array}$} & \multicolumn{3}{|c|}{$\begin{array}{c}\text { 浚渫によるストックマネージメント } \\
\text { 環境費用+浚渫費用 (A) }\end{array}$} \\
\hline$M=100$ & $174,930,000$ & $77,558,000$ & $11,546,000$ & $381,100,000$ & $150,330,000$ & $18,242,000$ \\
\hline$M=75$ & $124,510,000$ & $54,960,000$ & $7,632,800$ & $264,010,000$ & $103,190,000$ & $12,649,000$ \\
\hline \multirow[t]{2}{*}{$\mathrm{M}=50$} & $75,961,000$ & $33,043,000$ & $4,167,700$ & $154,200,000$ & $60,984,000$ & $7,432,900$ \\
\hline & \multicolumn{3}{|c|}{$\begin{array}{l}\text { 何もしない } \\
\text { 環境費用 (B) }\end{array}$} & \multicolumn{3}{|c|}{$\begin{array}{l}\text { 何もしない } \\
\text { 環境費用 (B) }\end{array}$} \\
\hline $\mathrm{M}=100$ & $231,350,000$ & $93,957,000$ & $11,595,000$ & $902,780,000$ & $319,180,000$ & $28,548,000$ \\
\hline$M=75$ & $152,300,000$ & $61,851,000$ & $7,632,800$ & $557,830,000$ & $197,220,000$ & $17,640,000$ \\
\hline \multirow[t]{2}{*}{$\mathrm{M}=50$} & $83,156,000$ & $33,772,000$ & $4,167,700$ & $277,880,000$ & $98,246,000$ & $8,787,400$ \\
\hline & \multicolumn{3}{|c|}{$\begin{array}{c}\text { ストックマネージメントの経済効果 } \\
(\mathrm{A}-\mathrm{B}) / \mathrm{B} * 100 \\
\end{array}$} & \multicolumn{3}{|c|}{$\begin{array}{c}\text { ストックマネージメントの経済効果 } \\
(\mathrm{A}-\mathrm{B}) / \mathrm{B} * 100 \\
\end{array}$} \\
\hline $\mathrm{M}=100$ & $-24.4 \%$ & $-17.5 \%$ & $-0.4 \%$ & $-57.8 \%$ & $-52.9 \%$ & $-36.1 \%$ \\
\hline$M=75$ & $-18.2 \%$ & $-11.1 \%$ & $0.0 \%$ & $-52.7 \%$ & $-47.7 \%$ & $-28.3 \%$ \\
\hline $\mathrm{M}=50$ & $-8.7 \%$ & $-2.2 \%$ & $0.0 \%$ & $-44.5 \%$ & $-37.9 \%$ & $-15.4 \%$ \\
\hline
\end{tabular}


サンゴ礁や生態系保全に関する環境費用を想定し たときの結果を表 4 右に示した. ストックマネージ メントの経済効果は格段に大きくなり，環境費用と 浚渫費用の割引現在価值は約半分となる. 沈砂池数 が一つのときでも， 3 年に 1 回浚渫を実施して赤土 流出を削減することが最適解となった。 サンゴ礁及 び生態系保全と赤土の関係は不明なことも多いが, 赤土流出によって多大な環境被害が想定されるとき には厳格な沈砂池マネージメントが必要となる。

\section{5. 考察：流域や地域による資源管理}

中村他（2010）は，北海道の畑作地帯にある 11 の沈砂池の維持管理状沉を調べ，ちち 6 つは堆砂機 能が全くない満砂状態, 9つの沈砂池では土砂の除 去が実施されていない実態を明らかにした。今後の 沈砂池の機能維持に関して, 地域全体での資源管理 を提案している点は興味深い.

流域・地域全体での沈砂池の資源管理には, どの ようなメリットがあるのであろらか，第一に，少な い費用で多くの環境被害を抑制できる、本稿の経済 分析に拁いても沈砂池が一つの場合には, 浚渫によ るストックマネージメントの効果は小さかったが, 流域内に多数の沈砂池がある場合には, 十分な経済 効果があるとの結果を示した。 また, 流域内の沈砂 池を同時に浚渫すれば，セットアップ費用や運搬費 の軽減につながる可能性もある（中村他，2010）. 重要なのは, 浚渫した土砂の有効利用の方法や保管 場所を地域・流域単位で検討できる点である。浚渫 した土砂を客土として農地に還元したり, 勾配修正 や法面工事のために使用したり, 堆積土砂の特性に 応じた地域資源の有効活用が期待できる。

第二に, 赤土対策は, 発生源と被害の特定が難し く污染者負担の原則を当てはめられない, 流域・地 域全体の利害関係者を巻き込むことで, 発生源や被 害の特定ではなく，地域資源の活用と保全に目を向 けるよらになる。 さらに, 地域全体での活動に対し ては，公的資金を導入しやすい点も重要である。「多 面的機能支払交付金」を利用した沈砂池の管理はそ の良い例である.

第三に，沈砂池を体験学習や教育の場として活用 する取り組みも始まっている，大澤他（2019）は， 沈砂池内には多種多様な水生昆虫類が生息している
ことから，子供たちに虫とり体験や環境教育と場と して沈砂池が利用できると提言している. 生物群の 生息場所（いわゆるビオトープ）としての機能に着 目し，それを地域の環境教育に生かそうとする取り 組みである.

沈砂池を所有する農業者個人にとって浚渫を実施 する経済的インセンティブはない.たと六海域の環 境保全のために, 自分だけで浚渫を実施しても, 他 の沈砂池で資源管理を行われていなければその効果 は薄くなってしまう。流域・地域による資源管理は, こうしたモラルハザードを防ぐ効果もあると考えら れる，沈砂池といら農業インフラを地域の公共財と してとらえ，その機能と価值を最大化する方策を地 域単位で検討できる点に扔いて，流域・地域による 資源管理は優れていると考光られる.

\section{6. まとめと結語}

本稿では，これまであまり注目されてこなかった 沈砂池の資源管理問題に焦点を当て，その資源管理 モデルの経済分析を行った，沈砂池に打いて浚渫が 実施されていない理由として，環境への影響が意思 決定に扮いて考慮されていない点に加光，将来の環 境費用を過少評価する短期的な意思決定及び沈砂池 の低い捕捉率の可能性を指摘した。 また，沈砂池一 の流入土砂量が多く, 流域内に多くの沈砂池が設置 されているところほど，沈砂池に打ける赤土対策の 経済効果が高いことを示した．以上のことから沈砂 池の資源管理は，流域・地域を中心とした沈砂池の 資源管理が有効であると考兄られる。

最後に，今後の課題を挙げて扣きたい，第一に， 流域・地域のよる沈砂池の資源管理のメリットを述 べたが，赤土対策の利害関係者は，農業関係にとど まらず漁業者，観光業者等多岐にわたっている．土 地改良区や農業集落を中心とした資源管理に加兄 て，今後は，沿岸漁業，サンゴ礁保全といった漁協 や自然保護団体等を含んだより広範囲な協力・連携 が求められてくるであろう5.

第二に, 沈砂池は土砂流出の多い農業地域に打い て重要な役割を果たしている農業インフラであるに も関わらず，その維持管理状況に関するデータや研 究は極めて限れられている。農業インフラのストッ クマネージメントを実施していくためには，既存の 
施設・設備のデータベース化が不可欠である．また， 限られた予算で沈砂池の長寿命化を図っていくため には, 維持管理状況に関わるデータも必要となる. 沈砂池の数, 場所, 維持管理状態に関するデータベー スの構築が望まれる.

\section{謝辞}

本研究は JSPS 科研費 JP18H04151「沿岸生態系と 農地を相互保全する地域再循環システムに基づく流 域型農業環境革新の展開」の助成を受けました.

\section{注}

1 沈砂池に関する工学的な研究として大澤他 (2004) の研究が 挙げられる.

2 これらの数值は 1 年あたりの経済的価値なので, 割引率を 0.01 とすると割引現在価值 (永続価值) はこれらの数值の約 100 倍になる.

3 ダムの貯水可能容積を再生可能資源としてとらえた研究に Kawashima（2007）が挙げられる. ダムの有効容積を初期容 積一堆積土砂容積と定義し, ダムに溜まった土砂を除去する ための経済分析を打こなっている

4 サンゴ礁の経済的価値については, Cesar et al.（2003）を参 照されたい，サンゴ礁の経済的価値は, 生物多様性に関する 価值等も含まれて極めて膨大であるが, 赤土との関連性につ いては明らかにされていないことも多い.

5 漁協による赤土防止対策と公論形成の場の必要性について は，家中（2000）を参照されたい。

\section{引用文献}

Cesar, H., L. Burke, and L. Pet-Soede (2003) The Economics of Worldwide Coral Reef Degradation, Cesar Environmental Economics Consulting (CEEC).

比嘉栄三郎 - 大見謝辰男 - 花城可英 - 満本裕彰 - 普天間朝好 $\cdot$ 古堅勝也・田代 豊・下地幸枝（1994）「土地改良事業の 赤土流出防止対策と SS 濃度の関係について」『沖縄県衛生
環境研究所報』(28) : 73-76.

家中 茂（2000）「地域環境問題に打ける公論形成の場の創出 過程一沖縄県恩納村漁協の赤土流出防止の取り組みから 一」『村落社会研究』7(1)：9-20. https://doi.org/10.9747/ jrs.7.1_9.

石垣市（2020）『統計いしがき』平成 30 年度（第 41 号）https:// www.city.ishigaki.okinawa.jp/soshiki/kikaku_seisaku/4/12/ 4483.html.

Kamien, M. I. and N. L. Schwartz (1991) Dynamic Optimization: The Calculus of Variations and Optimal Control in Economics and Management, New York: Elsevier.

Kawashima, S. (2007) Conserving reservoir water storage: An economic appraisal, Water Resources Research 43, W05417. https://doi.org/10.1029/2006WR005090.

Miranda, M. J. and P. L. Fackler (2002) Applied Computational Economics and Finance, Cambridge: MIT Press.

中村和正・小野寺康浩・鵜木啓二・古檜山雅之・細川博明・長 畑昌弘（2010）「火山灰の分布する烟作地帯に打ける沈砂 池の機能維持に関する研究」平成 22 年度土木研究所成果 報告書 : $1-8$.

小川茂男・島 武男・吉迫 宏・福本昌人（2005）「畑地の農 地保全管理による土壌流亡抑制効果」『農村工学研究所技 報』203:139-146.

沖縄県 (2014)「沖縄県赤土等流出防止対策基本計画」平成 25 年. 呉錫畢（2000）「沖縄県に打ける赤土污染の環境影響に関する 研究」『商経論集』29(1)：15-31. 沖縄国際大学商経学部. 大澤和敏・酒井一人 - 島田正志 - 池田駿介 (2004)「沖縄地力 の農業流域に抢ける土砂動態の検討」『水工学論文集』 48 : 1111-1116. https://doi.org/10.2208/prohe.48.1111.

大澤和敏・冨坂峰人・干川 明（2019）「沖縄に打ける赤土流 出防止に向けた取り組又」『農地保全の研究』(40) : 18-23. 農業土木技術者継続教育機構認定プログラム。

坂井教郎・森高正博・横川 洋（2015）「赤土流出対策の検証 と費用負担問題一石垣島の圃場データの分析から一」『農 林業問題研究』51(2)：65-73． https://doi.org/10.7310/ arfe.51.65. 